Momentum Shifts in the American Electric Utility System: Catastrophic Change-Or No Change at All?

Author(s): Richard F. Hirsh and Adam H. Serchuk

Source: Technology and Culture, Vol. 37, No. 2 (Apr., 1996), pp. 280-311

Published by: The Johns Hopkins University Press and the Society for the History of Technology Stable URL: http://www.jstor.org/stable/3106817

Accessed: 06/02/2014 13:17

Your use of the JSTOR archive indicates your acceptance of the Terms \& Conditions of Use, available at http://www.jstor.org/page/info/about/policies/terms.jsp

JSTOR is a not-for-profit service that helps scholars, researchers, and students discover, use, and build upon a wide range of content in a trusted digital archive. We use information technology and tools to increase productivity and facilitate new forms of scholarship. For more information about JSTOR, please contact support@ jstor.org. 


\section{Momentum Shifts in the American Electric Utility System: Catastrophic Change-or No Change at All?}

R I C H A R D F. H I R S H A N D A D A M H. S E R C H U K

Electric utility executives and several business analysts claim that the American electric utility system began to change in the 1970 s. They argue that the system, which binds together massive turbines, transmission lines, nuclear reactors, human decision makers, millions of customers, and countless other components, has somehow been transformed, even though its physical nature remains much the same. As evidence of the mutation, they point to the loss of control over the business of electricity generation and to the growing influence of scores of entrepreneurs, some of whom produce power with technologies once dismissed as fancies of the "counterculture." At the same time, environmental activists and interventionist regulators have realigned corporate business policies dramatically in some states by forcing utilities to enter the energy-efficiency business. Contrary to their business instincts, utility managers in these states must now "unsell" their product after nearly a century of aggressively promoting its use.

While we acknowledge the major changes under way in the electric utility industry, we remain critical of the view, often accepted unanalytically within the industry itself, that the American electric utility system has been profoundly reshaped. Certainly, we agree with those participants who cite evidence of permanent restructuring. Yet we interpret many recent events as ways for established utilities to retain essential social and economic control over their industry. In

Dr. HIRSH is professor of the history of technology and science and technology studies at Virginia Polytechnic Institute and State University (Virginia Tech). He is the author of Technology and Transformation in the American Electric Utility Industry (Cambridge, 1989) and several shorter pieces on the recent history and management of the utility industry. Dr. SERchuk is research coordinator of the Renewable Energy Policy Project at the Center for Global Change at the University of Maryland. He received his Ph.D. from Virginia Tech in 1995, with a dissertation titled "Federal Giants and Wind Energy Entrepreneurs: Utility-Scale Windpower in America, 19701990."

(C) 1996 by the Society for the History of Technology. All rights reserved. $0040-165 \mathrm{X} / 96 / 3702-0003 \$ 01.00$ 
other words, though we concede the presence of change, we classify it as conservative (at least up to the early 1990s), intended to maintain vital aspects of the current system, rather than as a radical deconstruction of the way the nation supplies, distributes, and consumes its electricity. Although both utility managers and their critics in the 1970s cast the system as rigid and endangered, it has proven able to assimilate numerous potential threats. Current policy makers and business analysts who warn of impending disintegration of the system may likewise underestimate its resilience and the ability of its human elements to defend their basic positions of control.

In this article, we employ Thomas Hughes's ideas about large technological systems to frame our discussion of the possibility of radical system change. After considering Hughes's work, we address two stresses that have challenged the traditional actors' control of the electric utility system: the emergence in a deregulated industry of new players who generate electricity, using California wind-power entrepreneurs as an example, and the impact of environmental activists, also primarily in California, who have encouraged utility companies to pursue conservation efforts. We describe two responses to those stresses: the incorporation of small-scale technologies into the electric supply grid, and the development of so-called demand-side management programs intended to increase energy efficiency. We then ask whether these responses signify radical structural changes or conservative modification of an essentially unchanged system. Finally, we offer a way to extend the conceptual value of Hughes's notions of technological change.

\section{Systems and Change}

As a framework for this discussion of systems change, we refer to the work of Thomas Hughes, whose Networks of Power: Electrification in Western Society and other works provide analytic tools for talking about change. ${ }^{1}$ Perhaps most important, Hughes demonstrates that the generation, transmission, and distribution of electricity occurs within a technological system. The continued existence of any such large technological production system depends on system builders' abilities to bind into a "seamless web" considerations that a casual observer might categorize as economic, educational, legal, administrative, and technical. Large modern systems knit these elements into a whole, with system builders constantly striving, in Hughes's words, to "construct or . . to force unity from diversity, centraliza-

${ }^{1}$ Thomas P. Hughes, Networks of Power: Electrification in Western Society, 1880-1930 (Baltimore, 1983). 
tion in the face of pluralism, and coherence from chaos." ${ }^{, 2}$ If the managers succeed, the system thrives and expands. As the system matures, it may effectively close itself. That is, the influence on it of the outside environment may ebb, perhaps because the system has expanded to encompass factors to which it might be vulnerable.

Hughes believes that humans play a special role in systems and act to control feedback between system performance and goals. And, of course, the capacity of the system to grow depends largely on the talents of the managers. Nevertheless, Hughes argues that modern developments tend to minimize the voluntary role of humans in technological systems and that managerial control decreases within an individual system as it matures.

Systems reach closure in various ways. Some companies try to ensure their dominance in a system by pursuing vertical integration, by which they manage all phases of a given commodity from raw material to final consumer product. In the electric utility system, the urge to integrate vertically can be seen in the career of Thomas Edison, who aimed not only to produce and deliver electricity but also to manufacture the equipment used in generating and consuming his product.

System closure also can be achieved by "capturing" the regulatory apparatus, by which institutions of bureaucratic oversight come to serve the interests of the controlling stakeholders. In the utility system, power company managers appeared to have successfully captured regulators, at least until the 1970s. During the 1930s, regulators in some states blocked creation of proposed cooperatives, sponsored by the Rural Electrification Administration (REA), so that established utility companies could skim off the best rural customers for their own. ${ }^{3}$ Regulators also gave favorable treatment to construction plans, valuations of the "rate base" on which utilities earn a profit, and rate reduction requests (as a form of competition against other fuels) after World War II and until the 1960s. ${ }^{4}$ While scholars differ as to the causes, they agree that regulators did indeed

\footnotetext{
"Thomas P. Hughes, "The Evolution of Large Technological Systems," in The Social Construction of Technological Systems: New Directions in the Sociology and History of Technology, ed. Wiebe E. Bijker, Thomas P. Hughes, and Trevor J. Pinch (Cambridge, Mass., 1987), p. 52.

${ }^{3}$ For charges of regulatory capture in the electric utility industry during the $1930 \mathrm{~s}$ and 1940s, see Marquis Childs, The Farmer Takes a Hand: The Electric Power Revolution in Rural America (New York, 1952), pp. 76-77.

${ }^{4}$ According to some critics, regulatory capture continued to occur through the 1980s. See Richard Rudolph and Scott Ridley, Power Struggle: The Hundred-Year War over Electricity (New York, 1986), pp. 187-92.
} 
help utility company management efforts to close the system and preempt interference by outsiders. ${ }^{5}$

According to Hughes, stakeholders also attempted to close the utility system by encouraging conservative invention-new technology that preserves the existing institutional arrangements. At the same time, participants tried to stifle radical invention, such as often originates outside a system and which might initiate competing systems. After establishing steam turbines and generators as the core generation technology in the early 1900s, system builders made good use of academic institutions and research and development laboratories owned by equipment manufacturers to maintain the dominance of that core technology for another fifty years. With almost no alternatives to fossil-fuel-burning equipment, utilities bought and helped develop increasingly sophisticated steam-turbine generators, whose incrementally improving thermal efficiencies and economies of scale contributed so much to the industry's growth and improved productivity until the $1960 \mathrm{~s}^{6}$ Managers viewed radical inventions outside this engineering realm as inimical to established financial and intellectual interests. Consequently, the industry came

\footnotetext{
${ }^{5}$ According to one school of thought, public utility commissioners struck an implicit bargain with power company executives because the legislators and civic leaders who had pushed for creation of regulatory bodies in the early 1900 s became apathetic soon thereafter. As the public outrage over industry abuses subsided, newly created commissions found they had little political power. State politicians gave regulators few resources for building their staffs or for broadening their oversight activities, and the commissions often became "dumping grounds for political hacks and cronies of the governor" (Thomas K. McCraw, Prophets of Regulation [Cambridge, Mass., 1984], p. 243). By making decisions amenable to the industry managers they supposedly oversaw, utility commissioners aligned themselves with a strong source of political and financial power, thus ensuring their survival. A second school of thought suggests that, in general, regulators suffer capture because they realize that, after their term of office, they can market only the specialized knowledge gained during their tenure to the industry they formerly supervised. Hence, to ensure future employability, they shape policy so as not to offend industry. A third model of capture seeks to discredit the popular notion that regulation arose as an effort by a benevolent government to police unscrupulous industries. Some economists and historians argue that the utility industry sought regulation, either to bar market entry by new players, or to obtain legitimacy and forestall government prosecution. Regulation, therefore, constituted part of a strategic plan to maintain control over part of the market. The various schools of thought regarding regulatory capture are explored in Douglas D. Anderson, Regulatory Politics and Electric Utilities: A Case Study in Political Economy (Boston, 1981), pp. 1-4; and George J. Stigler, "The Theory of Economic Regulation," Bell Journal of Economics and Management Science 2 (Spring 1971): 3-21.

${ }^{6}$ Richard F. Hirsh, Technology and Transformation in the Electric Utility Industry (Cambridge, 1989), p. 83.
} 
to rely more heavily on the conservative output of corporate engineers, who were perhaps more fettered by established ways of seeing problems, than on freewheeling individual inventors. ${ }^{7}$ Utility managers appeared eminently successful, dispelling scrutiny as they oversaw price declines of more than 90 percent in real, inflation-adjusted terms and an annual growth rate in consumption averaging 7 percent from World War II until 1973. ${ }^{8}$

Despite tendencies to mitigate novelties, systems can and do change. Though he rejects the idea that systems direct themselves, ${ }^{9}$ Hughes asserts that technological systems, "even after prolonged growth and consolidation, do not become autonomous; they acquire momentum." ${ }^{10}$ Elsewhere Hughes defines momentum as a "mass of technological, organizational and attitudinal components [that tend] to maintain their steady growth and direction." 11 The system's inertia, or tendency to continue along a given path, results from the synergy of educational and regulatory organizations, thousands of skilled individuals, millions of dollars worth of industryspecific equipment, and ingrained ways of looking at the world; together, all encourage the continuation of business as usual. Investment, Hughes points out, refers to more than just money. Large technological systems may appear autonomous, but for Hughes this autonomy reflects human managers' careful construction of the system so as to exploit the existing social environment.

Faced with the threat of radical change, "the people and investors in technological systems construct a bulwark of organizational structures, ideological commitments, and political power to protect themselves and the system." 12 In time, system participants may come to mistake unhindered momentum for system autonomy. Changes in the business environment that alter system momentum may then

\footnotetext{
${ }^{7}$ Hughes, “The Evolution of Large Technological Systems," pp. 56-62. For the development of utility management culture, see Hirsh, pp. 26-35.

${ }^{8}$ Hirsh, pp. $82-83$.

${ }^{9}$ Some observers of technological change posit some principle within the system itself that motivates its growth. Social theorist Jacques Ellul, for example, is usually read as a believer in the existence of technological autonomy; Ellul argues that "technique is autonomous with respect to economics and politics. ... Its progress is likewise independent of the social situation." Rather, Ellul contends that technology represents a prime mover that conditions all other species of social change "in spite of all appearances to the contrary, and in spite of all human pride." See Jacques Ellul, The Technological Society (New York, 1984), pp. 133-34.

${ }^{10}$ Hughes, "The Evolution of Large Technological Systems," p. 76.

"Thomas P. Hughes, American Genesis: A Century of Invention and Technological Enthusiasm, 1870-1970 (New York, 1989), p. 460.

${ }^{12}$ Ibid., pp. 460-61.
} 
provide a shock for managers and clients who believe in the inexorable forward progress of their supposedly autonomous system. As we will discuss, such a shock certainly occurred in the electric utility industry in the 1970s, when managers had taken as gospel the notion of steady "progressive" growth of electricity consumption and continuously improving power technologies.

Hughes's work focuses on the social construction of momentum in the electric utility industry, and it does not fully explore the conditions under which momentum might change. His most provocative statements on that subject come at the end of his American Genesis. "In the face of this conservatism and momentum," he asks, "what might bring the displacement of large-scale, centralized, hierarchically controlled production systems? What forces might counter the tendency of large technological systems to determine social change, even history?" 13 Hughes suggests three possibilities.

Given that the market forms such an important part of the environment of modern systems, a rapid shift in consumer inclinations might cause change. Hughes considers the example of the 1973 oil embargo, when increased fuel costs expanded the American market for smaller and more energy-efficient vehicles (especially those made in Japan), to the dismay of American manufacturers, who preferred selling bigger, more profitable cars. Ultimately, American automakers altered their production strategies to accommodate market preferences.

Second, system catastrophes, such as the accident at Three Mile Island, the explosion of the space shuttle Challenger, and the Chernobyl nuclear power plant disaster have become increasingly common. Not only highly interconnected and complex, these systems are embedded in a social milieu that demands, in the case of Chernobyl, increasing amounts of power or, in the case of the Challenger, frequent newsworthy launches. Catastrophic system failure indicts not only faulty machines but social values of technological progress as well. Hughes suggests that such failures may alert the public to the dangers inherent in pushing tightly coupled complex systems too hard or too far.

Third, Hughes finds radical change stemming from "a change in belief, attitudes and intentions comparable to a religious upsurge, or a religious conversion." 14 Hughes has in mind mass acceptance of values today considered counterculture, rejecting the materialism and the concentration of power embodied in large technological

${ }^{13}$ Ibid., p. 461.

${ }^{14}$ Ibid., p. 466. 
systems. He sees evidence of such change in new styles of small-scale, decentralized, and flexible management systems that appear better suited to today's uncertain economic growth and global marketplace. He concludes American Genesis by wondering whether the coming age of multinational corporations will demonstrate increasing decentralization or further imposition of hierarchical power.

To summarize Hughes's views, systems develop through human management of internal and external factors. They acquire momentum that is often-misleadingly-presented as autonomous motion and growth. As systems mature, they increasingly resist social construction. The most likely possibility for a radical change in momentum seems to be, in Hughes's phrase, "a confluence of contingency, catastrophe and conversion." 15

What are the chances of such a confluence in the American electric utility system, whose accretion of momentum Hughes has done so much to explicate? We begin by examining the stressful environment in which the electric utility system found itself in the early 1970 s and the nest of related technological, public policy, and cultural developments that provide superficial evidence of a greatly transformed utility system, especially as it operated in California.

First Stress: Deregulation and Introduction of New Actors

After earning a generally positive reputation in the aftermath of World War II as a well-regulated natural monopoly that extended near-universal service at steadily declining prices, electric utility companies suffered greatly in the $1970 \mathrm{~s} .{ }^{16}$ The energy crises of 1973 and 1979 sparked oil price hikes of more than 400 percent (coal prices increased by about 200 percent) during the decade, causing electricity rates to rise as well. From 1973 to 1983, residential customers saw rates jump by an average of 11 percent annually, which spurred sharply curtailed usage growth of only 2.5 percent per year. High price inflation, reaching more than 13 percent in 1980, also meant skyrocketing borrowing costs for the most capital-intensive industry in the country. ${ }^{17}$ As prices to consumers soared, regulatory commissions shed their role as captives to utility companies. Becoming more interventionist, they frustrated power company managers by denying the requested levels of "rate relief"- a euphemism meaning higher

\footnotetext{
${ }^{15}$ Ibid., pp. 470-71.

${ }^{16}$ By 1956 , more than 99 percent of American homes enjoyed electrical service; Bureau of the Census, Historical Statistics of the United States: Colonial Times to 1970, Part 2 (Washington, D.C., 1973), p. S-111.

${ }^{17}$ Hirsh, Technology and Transformation (n. 6 above) pp. 110-13.
} 
rates for consumers-and began working to protect customers' interests.

Though disconcerted by the new regulatory activism, utility managers, often trained as engineers, found more disheartening the deceleration of technical improvements in generating equipment, which had previously mitigated cost increases. Cramped by inflation, managers sought greater economies of scale from successively larger turbine-generator sets. In response to a frenzy of orders for new equipment in the 1960s and early 1970s, manufacturers abandoned their practice of refining their designs through small incremental steps, which had allowed the incorporation of gradually accruing operating experience into each successive model. Instead, as utilities' orders for ever-larger equipment came more rapidly, manufacturers designed new units without benefit of operators' experiences with previous models. By the 1970s, this new "design by extrapolation" process yielded huge machines-up to 1,300 megawatts (MW) each-which often proved unreliable and costly to maintain. ${ }^{18}$ Moreover, metallurgical problems prevented larger units from boosting the efficiency of fuel-to-electricity conversion, eliminating yet another means by which utilities traditionally reduced their cost of generating power. This socially constructed end of progress, which has been dubbed "technological stasis," helped create an unstable environment that challenged previous business assumptions and practices. $^{19}$

One such assumption was the rationale long used by utility managers to justify their natural monopoly status for generating electricity. Early in the century, utilities had won the right from state governments to exclusive retail franchise areas partly on the basis of their ability to exploit economies of scale and to make the best use of natural resources. That is, because of the high ratio of fixed costs to operating costs in the utility business and the apparent wastefulness of duplicated resources, policy makers accepted the argument that multifirm competition would lead to higher rates for customers. In return for their protected status, utilities agreed to regulatory oversight of rates and service-a concept trumpeted not only by progressive reformers before World War I but also by industry leaders who saw regulation as legitimation for a system that appeared poised for profitable expansion. Technological stasis eroded the notion of

\footnotetext{
${ }^{18} \mathrm{~A}$ megawatt, which equals 1,000 kilowatts $(\mathrm{kW})$, is a measure of the instantaneous demand for electrical power. For purposes of comparison, a toaster draws $1 \mathrm{~kW}$ of power, a stereo receiver $0.1 \mathrm{~kW}$, and a 60 -watt light bulb $0.06 \mathrm{~kW}$.

${ }^{19}$ Hirsh, Technology and Transformation, pp. 2-3.
} 
scale economies because bigger units did not necessarily provide the expected benefits. Moreover, some critics suggested that utilities' power plants, which converted about 35-40 percent of raw fuel into electricity, did not maximize resource efficiency.

This last criticism found a supporter in President Jimmy Carter, who made energy efficiency a major element of his National Energy Plan, passed by Congress in 1978. One of the laws making up the plan, the Public Utility Regulatory Policies Act (PURPA), included a provision that sought to optimize overall energy efficiency by encouraging "cogeneration" technology in papermaking, oil refining, and other industries that used large quantities of process heat. Cogeneration exploits waste heat from industrial processes to run generators that produce electricity for local use. An old technique, cogeneration had lost favor as power companies took advantage of larger-scale plants and attractive rates to entice industrial producers of electricity to subscribe to utility service..$^{20}$ The 1978 law sought to reverse this trend by encouraging companies outside the utility industry to produce steam and electricity in smaller and more efficient plants. By exempting the companies from federal and state laws that would have classified them as electric utilities, the law freed cogenerating firms from burdensome regulation. ${ }^{21}$ It also required utilities to interconnect with them through existing transmission lines and to purchase the excess electricity cogenerators produced at a rate equal to the power companies' own marginal cost of producing power. ${ }^{22}$

Though intended only to reduce American vulnerability to disruptions of the foreign fuel market by increasing energy efficiency, PURPA unexpectedly started a process of deregulating the electric utility industry. It did so by creating a special class of independent generators (known as "qualifying facilities" or "QFs") and guaranteeing them a market of regulated utilities required to purchase the QFs' power. Moreover, the QFs could enter and withdraw from markets at will, something utilities could not do because of their legal

\footnotetext{
${ }^{20}$ Cogenerators in 1922 produced almost 30 percent of electricity in the United States, much of it, along with steam, for industrial use. In 1960, however, industrial plants delivered 10.5 percent of the nation's electric power by using cogeneration technology, while in 1978, they produced only 3.5 percent. See Edison Electric Institute, EEI Pocketbook of Electric Utility Statistics, 34th ed. (Washington, D.C., 1988), p. 6.

${ }^{21}$ In particular, the law exempted cogenerators from portions of the Federal Power Act and the Public Utility Holding Company Act dealing with business organization and state regulation of rates and service (Public Law 95-617, Public Utility Regulatory Policies Act, sec. 210(e)(1)).

${ }^{22}$ Ibid., sec. 210 (b).
} 
responsibility to serve all customers within their franchise areas. Utility managers generally opposed the special treatment that QFs obtained, especially after the independents gained an increasing share of the generation market. (By 1992, cogenerators produced 15 percent of American electricity. ${ }^{23}$ To overcome the threat posed by the unregulated entities, some utilities unsuccessfully petitioned the Supreme Court to overturn PURPA. ${ }^{24}$ These actions suggest that PURPA-inspired deregulation quickly became a major stress for power company managers - the people previously in control of the electric utility system.

Aside from cogenerators, PURPA encouraged development of new technologies for producing power, such as those using biomass, waste, and other renewable resources (such as solar- and wind power) as primary energy sources..$^{25}$ These technologies previously had applications only where their expensive power output filled specific market niches. (For example, solar power proved useful in isolated areas where no utility transmission or distribution lines reached.) But PURPA provided incentives to expand the scope of these renewable sources of power, which, a few legislators hoped, would relieve dependence on foreign oil.

Though a federal law, PURPA was not implemented uniformly throughout the United States. Congress ordered the Federal Energy Regulatory Commission to set guidelines for instituting PURPA's mandates, but it left the states latitude in interpreting them, which was done in varying ways. In California, regulators applied the law liberally to spur creation of a healthy nonutility generation industry, which in turn helped alter the traditional utility system.

California's aggressive pursuit of "PURPA power" actually began before the 1978 passage of the act, when Jerry Brown won election as governor in 1974. A former Jesuit seminary student and devotee of Zen philosophy. Brown acquired the sobriquet "Governor Moon-

\footnotetext{
${ }^{23}$ Ann Crittenden, “Generating Competition: Electric Utilities Face a Host of New Rivals,” Barron's, February 3, 1993, p. 14.

${ }^{24}$ Federal Energy Regulatory Commission v. Mississippi, 102 Sup. Ct. 2126 (1982); and American Paper Institute v. American Electric Power Service Corporation, 103 Sup. Ct. 1921 (1983). The latter case established the legitimacy of PURPA's requirements that utilities pay QFs for their power and overcame utility objections concerning the requirement to interconnect the producers and transmission grids. For a summary and brief discussion of the case's implications, see "High Court Upholds Utility Rules of United States," New York Times, May 17, 1983, p. D5.

${ }^{25}$ Public Utility Regulatory Policies Act, sec. 210. Hydroelectric power was also offered special treatment under the law. Cogenerators, however, obtained the greatest benefits under PURPA. While most alternative energy systems could not exceed 30 megawatts to qualify for PURPA exemption, cogenerators could be any size.
} 
beam" because of his unconventional beliefs and sometimes eccentric behavior. Among his interests he counted small-scale, dispersed technologies, such as solar and wind power. By making politically astute appointments to the California Public Utilities Commission (CPUC), as well as the first appointments to the California Energy Commission, created in mid-1974 to shape overall energy policy, Brown changed the course of electricity policy in a state that was the fifth largest energy consumer in the world. ${ }^{26}$

To comply with PURPA, the CPUC in 1983 required utilities to purchase electricity from QFs at rates reflecting the commonly held view that energy prices would continue rising in the future. Most significantly, the commission required utilities to offer standardized contracts specifying fixed long-term purchase prices for QF power. The availability of these contracts, the commissioners believed, would aid potential QFs in obtaining financing by allowing them to anticipate future revenues. The simple contracts also lowered transaction costs for QFs, further facilitating market entry for entrepreneurs touting diverse technologies, ranging from conventional cogeneration plants to solar- and wind-powered projects. Known as Interim Standard Offer \#4, the contracts attracted scores of takers, especially when oil prices began declining in the early 1980s and entrepreneurs feared that the lucrative contract would be withdrawn. (From a peak of about $\$ 35$ per barrel in 1981, oil prices coasted to about $\$ 32$ in 1983 , only to plummet to about $\$ 10$ in 1986.) Although the CPUC suspended the contract offer in late 1985, many nonutility generation companies had already signed up for the rewarding deals, and the contracts remained valid for a decade, despite grumbling from utilities that had to honor them. ${ }^{27}$ When combined with tax credits and accelerated depreciation for the novel power-producing equipment provided by the federal and state gov-

\footnotetext{
${ }^{26}$ Barbara R. Barkovich, Regulatory Interventionism in the Utility Industry: Fairness, Efficiency, and the Pursuit of Energy Conservation (New York, 1989), chap. 4; and California Energy Commission, Energy Glossary and Guide to Programs, Agencies, and Legislative Committees (Sacramento, 1990), p. 71.

${ }^{27}$ Author (Hirsh) interview with Margaret E. Rueger, manager, Project Finance, Kenetech Windpower Corporation, February 27, 1991. Rueger represented US Windpower in negotiations with the CPUC and Pacific Gas \& Electric Company. See also Janine L. Midgen, "State Policies on Waste-to-Energy Facilities," Public Utilities Fortnightly 126 (September 13, 1990): 26-30, for more on the rate packages offered by California and other states. Some complaints about the highly attractive rate packages can be found in Sebastian J. Nola and Fereidoon P. Sioshansi, "The Role of the US Electric Utility Industry in the Commercialization of Renewable Energy Technologies for Power Generation," Annual Review of Energy 15 (1990): 99-199, esp. 111-12. The authors were utility managers at Southern California Edison.
} 
ernments, ${ }^{28}$ alternative energy took off. Cogeneration in California, for example, provided 6,000 MW of the state's 41,000 MW of demand in $1989 .{ }^{29}$ Meanwhile, wind- and solar-powered electricity burgeoned. During the 1980s, for example, California hosted 85 percent of the world's capacity of wind-powered electricity generation, ${ }^{30}$ as well as 95 percent of the world's solar capacity. ${ }^{31}$

The story of wind-powered generation illustrates the possibly radical changes in the American electric system in the 1980s. ${ }^{32}$ Though unfamiliar to recent generations of Americans, the pedigree of today's electricity-generating wind turbines extends back many centuries, if not millennia. In varying forms, wind-driven machines have enjoyed periods of substantial, though temporary, success. Colonial American millers, for example, erected European-style windmills to grind their grain when they lacked access to fast-running streams for the watermills they preferred. In the late 19th century, cheap, mass-produced, wind-driven pumps drew water for parched homesteaders on the plains of the American Midwest. After World War I, when electric utilities pursued dense urban markets rather than stringing lines to isolated farms, many rural Americans bought or built small individual wind-driven generating sets to charge the batteries that powered their radios and electric lights. ${ }^{33}$

Wind machines met the need for power in a variety of contexts, but wind technology in all its manifestations invariably lost ground to new sources of power. Though it costs nothing, the wind blows capriciously. Dependable coal-burning roller mills, which produced the whiter flour formerly available only to the rich, decisively edged out windmills in the 19th century. Wind-driven pumps and genera-

\footnotetext{
${ }^{28}$ Public Law 95-618, Energy Tax Act of 1978; C. Richard Baker, "Project Financing for Cogeneration Projects," Public Utilities Fortnightly 125 (March 15, 1990): 26.

${ }^{29}$ California Energy Commission, Electricity: 1990 Report, Publication P106-90-002, (Sacramento, 1990), pp. 3-11.

${ }^{30}$ Carl J. Weinberg and Robert H. Williams, "Energy from the Sun," Scientific American (September 1990): 146-55.

${ }^{31}$ Michael Lotker, Barriers to Commercialization of Large-Scale Solar Electricity: Lessons Learned from the Luz Experience, Sandia National Laboratories Report SAND91-7014 (Albuquerque, N.M., 1991), p. iii.

${ }^{32}$ For a more complete treatment of wind power, see Adam H. Serchuk, "Federal Giants and Wind Energy Entrepreneurs: Utility-Scale Windpower in America, 19701990" (Ph.D. diss., Virginia Polytechnic Institute and State University, 1995).

${ }^{33}$ For colonial windmills, see Walter Minchinton, "Wind Power," History Today 30 (March 1980): 31-35; and Volta Torrey, Wind-Catchers: American Windmills of Yesterday and Tomorrow (Brattleboro, Vt., 1976). For wind pumps, see Walter P. Webb, The Great Plains (Boston, 1931), pp. 333-48. For wind-driven generators in rural America, see Carol Lee, "Wired Help for the Farm: Individual Electric Generating Sets for Farms, 1880-1930” (Ph.D. diss., Pennsylvania State University, 1989).
} 
tors made sense on the American plains when no alternative existed, but the rising tide of cheap, centrally generated electricity, distributed in many cases by REA cooperatives, made wind machines largely a forgotten relic of the frontier, glimpsed occasionally by travelers on the nation's highways.

The first half of the 20th century saw only sporadic attempts to generate electricity from wind power. Most notably, Palmer Putnam and the S. Morgan Smith Company erected a 1,250-kilowatt $(\mathrm{kW})$ turbine at Grandpa's Knob in Vermont during the early 1940s, a unit not surpassed in size until the mid-1970s. The Smith-Putnam machine fed power into the Central Vermont Public Service Corporation grid for about two years, until the innovative machine "threw" a blade. Project planners attributed the failure to design shortcuts they had risked to avoid delays due to wartime material shortages. However, Central Vermont and the Smith Company opted not to pursue the project, as they doubted that they could construct and operate wind turbines at a cost competitive with that of other generating technologies. ${ }^{34}$

Putnam claimed in his final report that "the technical problems of the 1,250-kW wind turbine are understood and have been solved," but he conceded that bringing down the cost of wind power probably required government aid. ${ }^{35}$ Beauchamp Smith, former vice president of the Smith Company, told participants at the first federal wind-energy workshop in 1973 that the attempt to generate electricity from wind power succeeded technologically; "what it did not prove," he observed, "is that this can be done on an economically feasible basis!" 36 That both Smith and Putnam themselves described the project as a failure indicates their true goal: not simply to create a machine, but to integrate a generating technology into the profitoriented utility system.

To observers of the day, the Smith-Putnam experiment provided evidence that wind turbines could not compete economically with larger, centralized generation technology, even as part of a utility's overall generating mix. By the late 1960s and early 1970s, wind power had become a counterculture technology, advocated as an

\footnotetext{
${ }^{34}$ See, e.g., Frank R. Eldridge, Wind Machines, 2d ed. (New York, 1980), p. 24; Torrey, pp. 130-140; Tom Kovarik, Charles Pipher, and John Hurst, Wind Energy (Chicago, 1979), pp. 13-15. Our account draws on Palmer C. Putnam, Power from the Wind (New York, 1948); and Beauchamp E. Smith, "Smith-Putnam Wind Turbine Experiment" in Wind Energy Conversion Systems: Workshop Proceedings, ed. Joseph M. Savino (Washington, D.C., 1973), pp. 5-10.

${ }^{35}$ Putnam, p. 218.

${ }^{36}$ Smith, p. 6.
} 
ideological act of unplugging from the utility grid. In addition to its cleanliness and apparently infinite supply, advocates urged wind power's potential to decentralize power production, erode the power of giant corporations, and encourage individuals and communities to take responsibility for their own energy decisions.

The energy crisis of the 1970s spurred an acrimonious debate over the link between energy and social structure, and over the assertion that widespread adoption of small-scale, renewable-resource energy technology would benefit American society. Much of this debate made reference to physicist Amory Lovins. In a provocative Foreign Affairs article published in 1976, Lovins charged that our conventional energy economy had gone bankrupt, and he suggested that a switch to renewable energy sources could help bring about desirable social change. As an alternative to the prevailing energy system, which depended on rapid expansion of centralized high technology to increase energy supplies-a system Lovins called the "hard path"- he outlined a "soft path" utilizing "soft technologies." Soft, he explained, was "intended to mean not vague, mushy, speculative or ephemeral, but rather flexible, resilient, sustainable and benign. ${ }^{,{ }^{77}}$ Lovins argued passionately that soft technologies relied on renewable resources rather than on depletable energy capital, that they utilized accessible components rather than arcane high technology, and that they remained amenable to decentralized community or family control.

Lovins's prescriptions for social and technological change provoked irate responses. Physicists Aden and Marjorie Meinel, for example, professed themselves "chilled" that a physicist could so "distort physical reality." They interpreted Lovins as advising America to abandon high-technology and large-scale endeavors, which would, they charged, make "mankind once more a slave to the dispatches of a dispassionate environment and his own furies." The Meinels argued that adoption of small-scale dispersed technology such as small solar and wind installations would run counter to the historical trends of centuries, and prove "inconvenient, unreliable and costly" besides. They concluded by advising reliance on the leadership of established electric utilities, and pursuit of the "true option" of nuclear fusion power. Philosopher George Pickering questioned Lovins's suggestion that soft technologies resist the creation of technological dependence and commercial monopoly: "If the soft technologies are as commercially viable as Lovins maintains, they will attract investment and they will become absorbed in the

${ }^{37}$ Amory B. Lovins, "Energy Strategy: The Road Not Taken," Foreign Affairs 55 (October 1976): 77. 
web of commercial corporations competing in the manufacture, distribution and servicing of them." 38 Still other critics picked at the details of his technological and economic arguments, and maintained that his suggestions, while praiseworthy, failed to stand up to rigorous analysis. ${ }^{39}$

But to those who agreed with Lovins, small wind turbines seemed a logical element of his prescription for an alternative energy future. Indeed, several wind pioneers had explored the path advocated so strikingly by Lovins. Many accepted the proposition that a socially desirable energy future should be judged on grounds other than economic. For instance, in 1981 MotherEarth News described an apparently successful attempt by its staff to refurbish an early Jacobs $1.8-\mathrm{kW}$ turbine for household use. Significantly, the crew does not seem to have compared the cost of the turbine to the price of utility power. The partisan author's observation that "the power that is produced by the wind on the hill above will spin no meters, and will be accompanied by no bills" proclaimed not efficiency, but independence. ${ }^{40}$

Meanwhile, the electric utility industry exhibited little interest in such pursuits. As Lovins had frankly proclaimed, the soft energy path entailed not merely a change in technology, but a radical challenge to the prevailing technological system, with its attendant values, skills, ways of life, educational institutions, and so on. In the late 1960s and early 1970s, after decades of steadily increasing scale and decreasing prices, utility managers saw no reason to fix what, in their eyes, did not appear broken. While they may have paid lip service to the concept of renewable resource energy technologies, casting them as the energy sources of the 21 st century, utilities made only small investments in renewable energy research. ${ }^{41}$

Even as they reeled from the energy shock of 1973 , most utility managers remained resistant to the idea of renewable resource technology. The federal government, however, took modest steps in that

\footnotetext{
${ }^{38}$ See Aden Meinel and Marjorie Meinel, "'Soft' Energy Paths-Reality and Illusion," and George W. Pickering and Margaret N. Maxey, "The Road Not Takenand Wisely So: A Path Too Soft to Travel," both in Soft vs. Hard Energy Paths: 10 Critical Essays on Amory Lovins' "Energy Strategy: The Road Not Taken," ed. Charles B. Yulish (New York, 1977), pp. 70-76 and 77-110.

${ }^{39}$ Lovins answered some criticisms in Amory Lovins and his critics, Energy Controversy: Soft Path Questions and Answers, ed. Hugh Nash (San Francisco, 1979). 181.

40 "Wind Power Comes to Mother's Land," Mother Earth News 69 (May-June 1981):

${ }^{41}$ The 1978 Annual Report of Pacific Gas \& Electric Company observed that "a significant portion of US electric energy needs by the year 2020 could come from solar cells," while "wind energy may some day become an economical and practical supplemental source of electricity" (pp. 9-10).
} 
direction by establishing the Federal Wind Energy Program. The federal effort explored a variety of wind technologies, mapped the nation's wind resources, and researched institutional barriers to the adoption of wind power. However, the program element that received the most media attention (and funding) was a series of contracts with large aerospace and electrical equipment manufacturers (such as Boeing and General Electric) for design, construction, and testing of very large wind turbines for electricity generation. The largest of these multimegawatt turbines, the 3,200-kW "MOD-5B" machine erected in Oahu, Hawaii, by Boeing, the National Aeronautics and Space Administration, the Department of Energy, and Hawaiian Electric Industries, cost $\$ 54$ million to design and manufacture $;{ }^{42}$ the entire federal program, including research on smaller machines, cost some $\$ 460$ million. ${ }^{43}$

Private developers lacked the resources to fund turbines on the scale of the Federal Wind Energy Program's giants. Instead, venture capitalists seeking PURPA's incentives and associated tax credits devised an alternate technological variation-the "windfarm." With power pooled from several hundred moderate-size wind turbines, each producing $100-200 \mathrm{~kW}$, the windfarms sold electricity to utilities through direct connections to the local utility grid. Except for a single Hawaiian installation, independent investors undertook all windfarm construction, partly because utilities did not qualify for the incentives under PURPA. Wind entrepreneurs concentrated their efforts in California's Altamont, San Gorgonio, and Tehachapi Passes, long known for high winds, and known today for their fields of spinning turbines. ${ }^{44}$

By the end of the 1980s, the federal and venture-capital paths had

\footnotetext{
${ }^{42}$ Victor Laniauskas, "Letter from Hawaii," Far Eastern Economic Review 139 (January 21, 1988): 76 .

43 "'Renewable Energy Budget History (ERDA and DOE)," internal Department of Energy summary of spent appropriations, fiscal year 1975 to fiscal year 1991, courtesy of Daniel F. Ancona (in authors' possession). Another source estimates federal research costs between 1979 and 1987 at $\$ 450.9$ million; see Fred J. Sissine and Michele Passarelli, "Renewable Energy Technology: A Review of Legislation, Research and Trade," Congressional Research Service, Report no. 87-318 (Washington, D.C., March 1987), p. 29.

${ }^{44}$ For another view of the California wind energy business, $\rightarrow:$ Robert W. Righter, "Wind Energy in California: A New Bonanza," California History 73 (1994): 142-55. On the contributions made by Danish companies in wind-turine technology, much of which was used on the California hillsides, see Matthias Heymann, "Why Were the Danes Best? Social Determinants of Wind Technology Development in the 20th Century" (seminar paper presented to the Centre de Recherche en Histoire des Sciences et des Techniques, Centre National de la Recherche Scientifique, Paris, December 20, 1994).
} 
led to markedly different results. The federal program produced about a dozen giant turbines, culminating in the Oahu MOD-5B. But by 1992, that last giant wind turbine had been shut down due to poor economic performance and chronic malfunctions. ${ }^{45}$ To the chagrin of the counterculture, household-scale turbines in the range of $1 \mathrm{~kW}$ (such as the Mother Earth News machine) proved equally unable to capture market share, either in the residential or the windfarm sector, largely because manufacturers failed to develop designs that produced electricity more cheaply than could utilities.

By contrast, the privately financed windfarm concept thrived. Against the expectations of critics such as California's Governor George Deukmejian, who asserted in 1984 that "the windmill industry would disappear into the desert sands without" government-mandated incentives, windfarms survived the expiration of federal tax credits in 1985 and the loss of California state support a year later. ${ }^{46}$ As of 1992, the United States had 1,619 $\mathrm{MW}^{47}$ of installed wind capacity, 99 percent of it in California, where 15,500 turbines met 1.2 percent of the state's electricity demand. ${ }^{48}$ The California Energy Commission in the early 1990s estimated the cost of electricity generated by wind turbines at 4.7-7.2 cents per kilowatt-hour $(\mathrm{kWh})$, making utility-financed wind energy projects a cheaper option than nuclear plants, although slightly more expensive than coal boiler plants. ${ }^{49}$ In 1994 at least one California firm was willing to sign contracts to supply wind power to utilities at 5 cents per $\mathrm{kWh}$, about half the price of electricity generated by the Pacific Gas \& Electric Company's (PG\&E) own Diablo Canyon nuclear power plant..$^{50}$ In short, many California managers and policy makers viewed wind power as commercially feasible and highly competitive. ${ }^{51}$ Because of rapid techno-

4ว “'Hawaiian Electric Quits Business," Wall Street Journal, October 8, 1992, p. C18.

${ }^{46}$ Ellen Paris, "The Great Windmill Tax Dodge," Forbes 133 (March 12, 1984): 40.

${ }^{47}$ Statement of Michael L. Marvin of the American Wind Energy Association; House Committee on Ways and Means, Comprehensive Energy Policy Act: Hearings, 102d Cong., 2d sess., April 28, 1992, p. 231.

${ }^{48}$ Lisa Richardson, "Windmill Plan Could Re-energize an Industry," Los Angeles Times, October 5, 1992, p. B3.

${ }^{49}$ Nuclear plants produced power at from 5.3 to 9.3 cents $/ \mathrm{kWh}$ while natural gas plants could sell power for 5.3-7.5 cents/kWh; California Energy Commission figures quoted in American Wind Energy Association, "Wind Energy and Electricity Rates," [early 1990s].

${ }^{50}$ Kenetech Windpower signed contracts for this price; PG\&E's cost at its Diablo Canyon plant in 1994 was almost 12 cents per kWh. See PG\&E, 1993 Annual Report, p. 38.

${ }^{51}$ American Wind Energy Association, "Comments by the AWEA for the $1994 \mathrm{Bi}$ ennial Report on Repowering California's Wind Industry" (Washington, D.C., May $27,1993)$, pp. 3-4. 
logical advances in wind power, several utilities planned windfarms in the Midwest, which studies indicate has greater wind resources than California.$^{52}$ And in Massachusetts, the New England Electric System (NEES) signed a contract with Kenetech Windpower for the first major windfarm in the East. ${ }^{53}$

Deregulation of the generation sector of the utility industry, in a period in which conventional generation technology was static, thus constituted a major stress on the once-stable system. PURPA opened the door for non-utility generators, and suddenly utility companies lost control over one element of their business. At the same time, the success of some small-scale technologies, such as wind turbines, suggested that the system might modify its preference for centrally controlled fossil-fuel and nuclear power plants and begin to incorporate decentralized technologies, some of which had long been applauded by America's counterculture. On the surface, at least, it appeared that the electric utility system had changed markedly in response to the stress of deregulation, despite the desires of the utility managers who were traditionally regarded as the system's primary decision makers.

\section{Second Stress: New Business and Regulatory Policies}

The environmental movement created a second stress that altered the electric utility system by empowering a new set of players. Modern environmentalism burst into public discourse with the publication in 1962 of Rachel Carson's Silent Spring. ${ }^{54}$ The subsequent surge in public enthusiasm for environmental protection, symbolized by events such as 1970's Earth Day, impelled Congress to create the Environmental Protection Agency (EPA) ${ }^{55}$ Environmental opposition to the utility industry centered on construction of new fossilfuel and nuclear power plants. But while new EPA rules requiring

\footnotetext{
${ }^{52}$ Michael C. Brower, Michael W. Tennis, Eric W. Denzler, and Mark M. Kaplan, Powering the Midwest: Renewable Electricity for the Economy and the Environment (Cambridge, 1993).

53 “East Breaks West's Wind-Power Monopoly," Wall Street Journal, August 31, 1993, p. B1.

${ }^{54}$ For a discussion of the birth of the environmental movement, see Samuel P. Hays, Beauty, Health, and Permanence: Environmental Politics in the United States, 19551985 (Cambridge, 1987).

${ }^{55}$ Not all Americans joined the clamor. Many disenfranchised minorities considered the outcry over the environment a distraction from their own struggle to obtain acceptable housing, jobs, and education. See, e.g., "To Blacks, Ecology Is Irrelevant," Business Week, November 14, 1970, p. 49. Of course, it served the interests of environmentalism's opponents to note such fractures; in so doing, they trivialized the movement as the fetish of middle-class dilettantes.
} 
submission of environmental impact statements before building power plants may have slowed construction somewhat, the regulations did not require most managers to alter their behavior noticeably.

The picture changed partly as a result of the work of special-interest advocacy groups. In particular, organizations such as the Environmental Defense Fund (EDF) took a novel approach toward challenging utility management practices. Abandoning exclusive reliance on public education as the primary method of winning support for environmental policies, the EDF used litigation against utilities to restrict construction of power plants. In an especially noteworthy development, the organization began in 1976 to employ PG\&E's own planning models to argue that a combination of renewable energy technologies and conservation would both satisfy California's electricity needs and increase returns for PG\&E's investors. ${ }^{56}$

The new environmental strategy contributed to the stress already building on the utility system. In California, it motivated previously quiescent state regulators to take an active role in negotiations concerning electricity production and delivery. Just as significant, litigious environmentalism struck a serious psychological blow against utility managers. In an unprecedented affront, a group of liberal lawyers had successfully challenged the inner workings of major corporations. They had also publicly questioned the technological competence and business savvy of the managers, who considered themselves hardworking, underappreciated public servants. The humiliation of this process, quite apart from its legal effects, should not be underestimated.

As part of their rhetorical and substantive arsenal in the 1970s and 1980 s, the EDF and other environmental groups advocated using technological "fixes" as alternatives to power plants. These fixes included some alternative energy supply systems, such as wind turbines, which rapidly approached maturity in this period. But so did technologies that reduced energy demand by increasing efficiency in appliances and equipment. Through the efforts of entrepreneurial companies, university professors such as Arthur Rosenfeld, a Berkeley physicist turned energy-efficiency expert, and advocates like Lovins, research and development to improve energy efficiency burgeoned. In lighting alone great strides were made. Consuming about 25 percent of all power, electric lighting depended largely on the century-old technology of the incandescent bulb-which has been described as an electric heater that produces light as a by-prod-

\footnotetext{
${ }^{56}$ On the EDF, see David Roe, Dynamos and Virgins (New York, 1984).
} 
uct. New compact fluorescent lights and electronic ballasts used 75 percent less electricity than incandescent lights while providing equivalent illumination. Development of electronically adjustable speed drives for electric motors also occurred rapidly in the 1980s, yielding savings of 20 percent for this important component of commercial and industrial electricity consumption. And improvements in home refrigeration units provided great savings as well. While the average new refrigerator in 1971 used $1,726 \mathrm{kWh}$ per year, a new one produced in 1980 used only $1,280 \mathrm{kWh}$. By 1992, a new refrigerator's average consumption had declined to about $690 \mathrm{kWh} .{ }^{57}$ Surveying these and other commercially available energy-efficiency devices in late 1990, prominent energy analysts like Lovins concluded that electricity consumption could be reduced by $30-75$ percent by the year 2010 without any changes in behavior or lifestyle. ${ }^{58}$

When employed by utility companies as part of regulator-mandated programs, these energy-efficiency technologies became known in the mid-1980s as part of an approach called "demand-side management" or "DSM." Demand-side management focused on customers' demand for useful energy services rather than on a utility's ability to supply power. Though DSM subsumed activities once called "conservation," many DSM advocates avoided that term because of the implication, left over from the days when a cardigan-clad President Carter admonished the American public to turn down their thermostats in the winter, that conservation meant deprivation. According to these advocates, effective DSM programs achieved energy savings in an economically efficient fashion. With a rebate from New York City's Consolidated Edison Company, for example, the American Express Company upgraded the lighting in its Manhattan office in 1992, resulting in better lighting and energy savings of about 4.5 million $\mathrm{kWh}$ annually, worth about $\$ 280,000 .{ }^{59}$ Some people have argued that utilities have been in the DSM business for decades, initially because of their wish to increase customers' demand for electricity. But since the mid-1980s,

\footnotetext{
${ }^{57}$ Refrigerator usage data from Arthur Rosenfeld, Lawrence Berkeley Laboratory, letter to Hirsh. See also Mathew L. Wald, "Utilities Offer $\$ 30$ Million for a Better Refrigerator," New York Times, July 8, 1992, p. 3.

${ }^{58}$ Arnold P. Fickett, Clark W. Gellings, and Amory Lovins, "Efficient Use of Electricity," Scientific American (September 1990): 66.

${ }^{59}$ The company benefited from the help of the Environmental Protection Agency's "Green Lights" program, which provides information about energy-efficient lighting systems and ways to finance lighting upgrades. See Environmental Protection Agency, Green Lights Program Report (Washington, D.C., 1992), p. 2, Green Lights: The Second Year, EPA 430-R-93-005 (Washington, D.C., 1993), p. 10, and Green Lights: An Enlightened Approach to Energy Efficiency and Pollution Prevention, EPA 430-K-93-001 (Washington, D.C., 1993), pp. 10-11.
} 
the term has been used primarily to describe technologies and techniques that provide the same level (or a higher level) of electrical services while using less energy.

Though gaining momentum among conservation advocates and business people who saw economic benefits from reduced energy usage, the notion of demand-side management did not at first appeal to most electric utility managers. Some utilities, such as California's PG\&E, were pushed into the conservation business by regulators. In the mid-to-late 1980s, the company's managers resisted energy-efficiency efforts because the utility owned excess generating capacity and because energy prices had declined substantially since earlier in the decade. Simply put, managers believed that conservation did not make as much economic sense for customers as when energy prices were high. Moreover, from a cultural point of view, some managers felt that their business was to sell electricity, not "unsell" it, as was required with DSM programs. ${ }^{60}$

Perhaps most important, utility managers resisted environmentalists' efforts to encourage DSM because traditional regulation allowed utilities to earn profits for shareholders only when they sold electricity. Though companies like PG\&E had encouraged some conservation efforts since the energy crisis, thus deflating potential earnings, they did so because of the pressure to be good corporate citizens and because of prodding by their state's regulatory bodies. ${ }^{61}$ But managers argued that by encouraging DSM efforts to the extent advocated by environmental activists, utilities would be damaging their companies' economic integrity and their ability to provide reliable service to customers in the future.

Utility executives' antipathy toward DSM efforts often revealed itself in contentious regulatory hearings, at which participants espousing environmental goals lashed out against companies' proposals for building new power plants. In some cases, regulators agreed with the intervenors, penalizing utilities that did not devote enough effort to DSM by reducing the allowed rate of return on their investments and by disallowing recovery of DSM expenses they incurred. ${ }^{62}$

\footnotetext{
${ }^{60}$ Richard F. Hirsh and Bettye H. Pruitt, "The Background, Origins, and Formative Phase of the Advanced Customer Technology Test (ACT ${ }^{2}$ ) for Maximum Energy Efficiency"' (report for Pacific Gas \& Electric Co., San Francisco, 1993), p. 35.

${ }^{61}$ To be absolutely fair, one must recognize that some utilities objected less strenuously to conservation efforts because they reduced the companies' need to build new and expensive power plants. Still, utilities made money only when they sold power. When they had excess capacity, as many did in the mid-1980s, conservation efforts seemed to make little sense.

${ }^{62}$ Jonathan Raab, Using Consensus Building to Improve Utility Regulation (Washington, D.C., 1994), p. 100.
} 
After enduring several of these fracases in the mid-1980s, a few system participants sought to develop "collaborative" efforts to achieve goals advanced by environmentalists and utilities.

In Massachusetts, the Conservation Law Foundation, a group that used litigation to achieve environmental objectives, and the New England Electric System worked together in 1988 to develop a comprehensive DSM program that also provided the company a financial incentive to participate. The onetime adversaries first persuaded regulatory bodies in three New England states to give up the traditional formula used to determine utility revenues, which was based on the number of kilowatt-hours sold. Instead, they agreed on a payment system that gave the company a portion of the economic savings realized by its customers who took advantage of aggressive DSM programs. The New England Electric System found the financial motivation sufficient to sustain its managers' interest. As the company's president acknowledged good-humoredly after entering into the agreement with the conservation group, "you have to give the rat some cheese." ${ }^{63}$ For NEES, the cheese amounted to $\$ 15$ million after spending \$92 million on DSM programs in $1992 .{ }^{64}$ In California, environmental litigators employed a similar approach. After embarrassing the state's utilities by demonstrating how their conservation efforts had lagged since 1985, the Natural Resources Defense Council worked with electric and gas utilities in a 1989 collaboration that allowed some utilities to retain 15 percent of the energy savings enjoyed by their customers, making energy conservation a lucrative business indeed..$^{65}$

As an example of the eagerness some utilities demonstrated for DSM programs, consider Pacific Gas \& Electric. Marking an aboutface from the year before, when it claimed it had done all that was possible in the conservation realm, the firm announced in 1990 that it would displace 75 percent of about $2,500 \mathrm{MW}$ of planned capacity additions for the decade with DSM measures. Besides pursuing aggressive educational efforts to make customers and building con-

${ }^{63}$ John W. Rowe, president of New England Electric System, "Making Conservation Pay: The NEES Experience," Electricity Journal 3 (December 1990): 19.

${ }^{64}$ John W. Rowe and Cheryl A. LaFleur, "Making Lemons into Lemonade," Conservation Law Foundation Newsletter (Fall 1992): 7. Since the $\$ 92$ million investment was reimbursed to the company through customer rates, the company's return on investment was effectively infinite.

${ }^{65}$ The public utilities commission approved the plan in 1990. For the history of the collaborative process, see Jonathan Raab and Martin Schweitzer, "Public Involvement in Integrated Resource Planning: A Study of Demand-Side Management Collaboratives," Oak Ridge National Laboratory publication ORNL/CON-344, February 1992. 
structors aware of new technologies, the utility offered generous rebates to offset the higher prices customers had to pay for more efficient appliances, lighting systems, motors, and the like. The company developed this plan, which boosted DSM spending from \$84 million in 1989 to $\$ 150$ million in 1991, as part of an overall environmental program that, it claimed, would benefit everyone. ${ }^{66}$ As part of the bargain with regulators and public interest groups, PG\&E would earn handsome returns even as it sold less electricity. Customers would see lower electricity bills due to their greater energy efficiency and because the utility would not need to raise rates as much as if it built costly new plants. Finally, society at large would benefit by experiencing reduced power-plant emissions in a state cursed with air pollution problems. The program also had more widespread consequences, the company claimed, since it would reduce the fossil-fuel combustion that contributes to the (still-debated) phenomenon of global warming. Pacific Gas \& Electric thus embraced a policy that corporate executives had previously viewed as unacceptable. In response to the stress of the hitherto combative environmental movement, system participants had developed a collaborative strategy and agreed to seek regulatory change so that utilities could profit from DSM activities. ${ }^{67}$

The New England Electric System and PG\&E were not alone in developing DSM programs. By the end of 1991, at least twenty-four utilities in ten states had participated in similar collaboratives, in which regulatory bodies changed rules so that utilities could profit from pursuing DSM programs. ${ }^{68}$ In many states, regulators viewed what had occurred elsewhere favorably and started implementing similar rules for increasing DSM efforts without undergoing the collaborative process. It appears, then, that the goals of many environmental groups had been realized, with utility executives embracing DSM after they found they could make a good business out of it.

\section{Conclusion: Radical Structural Change?}

When comparing the attitudes and behaviors of power company managers in the early 1990 s to those of two decades earlier, it seems that a large part of the utility system has undergone a radical change. This article has highlighted two features of that change. First, a system once characterized by centralized generation and managerial

\footnotetext{
${ }^{66}$ PG\&E, "Annual Summary Report on Demand Side Management Programs" (March 1990 and March 1992).

${ }^{67}$ On collaboratives and PG\&E, see Hirsh and Pruitt (n. 61 above), pp. 33-38.

${ }^{68}$ Raab and Schweitzer, p. 1.
} 
control opened up to allow decentralized generating technologies, such as wind turbines, as well as a set of entrepreneurial human actors who had little interest in maintaining the previously monolithic utilities. Second, managers who formerly viewed the environmental movement as a destructive countercultural force had incorporated some of the movement's goals, such as new approaches to demand-side management, into their corporate strategies. It appeared, then, that the utility system had undergone dramatic changes in technology, source of human control, and even guiding strategies and attitudes.

These changes suggest that Hughes's conditions for radical change- "a confluence of contingency, catastrophe and conversion"- -have been met in the American electric utility system. The market for electricity did receive a serious jolt in the early 1970s after the energy crisis caused prices to escalate and the growth rate in usage to decline precipitously. And while the California power industry has not had a highly publicized catastrophe, the possibility of such a disaster was in the news, particularly when it was discovered that the Diablo Canyon nuclear reactor straddled the San Andreas Fault and, in addition, had been built from reversed blueprints. ${ }^{69}$ And, in a sense, there has been an apparent conversion in American attitudes toward energy and the environment, as demonstrated by some utility companies' acceptance of DSM measures.

Utility managers themselves harbored no doubt that their industry had undergone cataclysmic changes. For instance, in the watershed year of 1987, CEO Richard Clarke of the Pacific Gas \& Electric Company complained bitterly that an incoherent legal environment forced his company to operate as a traditional, regulated utility in its core residential and commercial markets, while obliging it to compete for industrial customers against new power-producing entities benefiting from regulation that discriminated against conventional utilities. Meanwhile, Clarke's colleagues bemoaned the disintegration of their closed and fraternal management culture. Edwin Lupberger, chairman and president of Middle South Utilities, sighed that utility CEOs had lost the authority to "sit down in a room" and

${ }^{69}$ PG\&E, "1981 Annual Report,” p. 3; Bryce Nelson, "Nuclear Panel Suspends Diablo Plant License," Los Angeles Times, November 20, 1981; p. I1; "Diablo Canyon Loses Its License," Newsweek, November 30, 1981, p. 98; and "Utility Apologizes to NRC for Nuclear Plant Problems," Los Angeles Times, November 11, 1982, p. I3. For review of the problems encountered by PG\&E with its Diablo Canyon plant, see Tom Redburn, "PG\&E's Nuclear Hope Turns into a Disaster," Los Angeles Times, March 16, 1982, p. I1. 
implement the policies they judged optimal for the electric system. "The times," Lupberger conceded, "have changed."

By 1990, utility managers diverged in their outlook. Some looked enthusiastically to a new era of financial opportunity in which lean, flexible companies would thrive. Others remained recalcitrant, like CEO and chairman Walter McCarthy of the Detroit Edison Company, who warned that the benefits of the changes to the ratepayer would be "trivial." Still others, like Middle South's Lupberger, pragmatically tried to put behind them the "political infighting, animosities and regulatory problems" of the 1970s and 1980s, in order better to decipher the new operating environment. Almost unanimously, however, the executives agreed with Chairman Richard Flynn of the New York Power Authority that "the old world is definitely gone."70

But let us look again at these events. Did they cause deep structural changes, or did utility managers simply make tactical responses to system stresses, with the hope that they could continue to operate normally, or as close to normally as possible? We have already noted how managers seek to retain control over as many variables in their systems as possible. In the "golden age" before the 1970s, utility managers clearly controlled nearly all variables in the electric system. Because of their long success in reducing the marginal cost of electricity, regulators endorsed almost all the plans utilities made for constructing power plants, transmission lines, and other facilities. Customers, satisfied by the cheap, dependable service they received (at least after service reached the hinterlands, due to the efforts of the REA and other factors), assumed that state commissions adequately represented their interests, and they eventually ceased to participate actively in the operation of the system. Outsiders rarely interfered, and managers enjoyed carte blanche to run their systems as they saw fit. The stresses of deregulation and environmentalism, however, challenged the managers, who in response sought ways to retain control.

It is worth recalling Hughes's distinction between conservative and radical inventions. The former, he suggests, preserve technological systems; they frequently originate with scientists or engineers with a stake in the existing system, such as those employed by indus-

\footnotetext{
${ }^{70}$ Lou Iwler, "Issues for 1985: Competition Heats Up as New Plant Comes on Line," Electrical World (January 1985), pp. 17-24; "1987 to Spotlight Competition and Deregulation," Electrical World (January 1987), pp. 15-20; "The Big Issue Is Deregulation," Electrical World (January 1988), pp. 11-20; "The Political Train Is on the Track," Electrical World (January 1990), pp. 11-15; H. A. Cavanaugh, "The Big Issues for 1993," Electrical World (January 1993), pp. 9-23.
} 
trial research laboratories. A radical invention, on the other hand, often comes from independent inventors. The existing system cannot incorporate the new technology, which may form the cornerstone of a new system. ${ }^{71}$

The giant wind turbines envisioned by aerospace and electricalequipment manufacturing firms working on federal contracts were a typically conservative invention. Though development of the machines took place outside of the utility industry, the products of the Department of Energy's giant turbine effort embodied the management values and economic assumptions of the established utility system-in this case, enormity of scale. For reasons described earlier, utility managers had met growth in consumers' electricity demand during the postwar period by installing increasingly large generating plants. Not only were large generating plants thought to capture economies of scale; they also came to symbolize the "macho" outlook of the system's human managers. Proponents of large wind turbines in the utilities, the federal government, and the equipment manufacturing firms seems to have shared the notion that electricity demand would continue unabated, and they conceptualized additions to generating capacity, including "alternative" technologies, in the largest feasible units. Additionally, the industry designed and produced the giant turbines so they could be plugged into the slots in the existing grid that would otherwise be filled by conventional coal or nuclear plants. By using the turbines in this way, the machines meshed well with the goals, values, and processes of the existing system. To return to Hughes's terminology, the giant turbines were conservative inventions because they would preserve and expand the existing system. ${ }^{72}$

Did the windfarms then represent a radical invention? They were a significant departure from past practice. Most notably, independent entrepreneurs rather than utility companies owned and controlled these generating facilities, made up of small-scale turbines. With the introduction of windfarms, utility managers lost significant control over the timing, quantity, and cost of producing electricity. And while modern wind turbines are not precisely low-tech, they are cer-

\footnotetext{
${ }^{71}$ Hughes, American Genesis (n. 11 above), pp. 57-59.

${ }^{72}$ This may in fact account for the failure of the giant turbines to be adopted. By the mid-1980s, increases in demand and the pace of construction were less predictable, contingent on local needs. Windfarms, which can rapidly be constructed in sizes finely matched to utility needs, suited the energy market. Giant turbines, by contrast, shared the unwieldiness and inflexibility of the giant fossil-fuel and nuclear plants with which they were intended to compete. Perhaps the giants were simply inappropriate for the new energy market.
} 
tainly more so than the nuclear reactors that many managers still looked to as the future of electricity production.

But the answer must still be no. As an example of what truly radical change in the system might have looked like, consider Lovins's vision of "soft" technology described earlier.$^{73}$ California does not exhibit, either as cause or effect of the wind boom, the social change on the part of electricity users that Lovins propounded. The home wind movement typified by the household machine described in Mother Earth News stressed the lifestyle changes necessary for such fundamental social change to occur. Because of the small power output of a home wind turbine, it might, for example, be necessary to change the times and places of housework to take advantage of natural light and reduce reliance on electric lighting, or even to adjust cultural standards of cleanliness. By contrast, the California windfarms are transparent to electricity users: that is, they require no lifestyle changes at all on the part of consumers. One strongly doubts whether Altamont Pass would sport a single turbine if incorporation of wind power into the electric system required PG\&E's customers to alter their daily routines.

With passage of the National Energy Policy Act of 1992, even the prevailing pattern of windfarm ownership stands in question. One important provision of that law revises the Public Utility Holding Company Act of 1935, allowing utilities to own unregulated powergenerating subsidiaries. As a result, utilities can now own windfarms, and the time since passage has seen a flurry of interest in wind development by a number of utilities, chiefly in the upper midwestern states, whose wind resources are the best in the world. ${ }^{74}$ We suspect that the next decade may bring the demise of venture capital in the wind industry, as utilities finance and operate their own windfarms. ${ }^{75}$

\footnotetext{
${ }^{73}$ Of course, Lovins represents only one possible version of radical change. Some Progressives of the early 20th century advocated a large-scale government-managed public power system that, while quite unlike Lovins's proposals, would have produced an electric system equally different from present reality.

${ }^{74}$ Brower et al. (n. 53 above), p. 12.

${ }^{75}$ In addition to the ownership of windfarm projects, renewable energy companies themselves reflect the growing interest of conventional sources of capital in this purportedly radical business. For example, the Kenetech Windpower Corporation, once America's most successful windfarm developer and wind-turbine manufacturer, listed as major investors the Allstate Insurance Company, the F. H. Prince Companies, and the Hillman Companies. Although PURPA prohibits utilities from owning wind farms, corporations providing debt or equity to Kenetech include subsidiaries of the Florida Power \& Light Co., Niagara Mohawk Power, PacifiCorp, and the Iowa-Illinois Gas \& Electric Co., in addition to Aetna, John Hancock Insurance, Chrysler Financial, the Security Pacific Bank, and Westinghouse. Taylor Moore, "Excellent Forecast for Wind," EPRI Jourmal 15 (June 1990): 23.
} 
If that turns out to be the case, the existing electric utility system will have completely digested the threat to it presented by the most successful renewable energy resource technology. To be sure, certain benefits will accrue to American society. Wind turbines do not produce particulate pollution, and they reduce reliance on Middle Eastern oil and politically unpopular technologies such as nuclear power plants. (Wind-power developers still encounter some resistance, however, on the basis of visual pollution and danger poised to birds by the large turbine blades.) ${ }^{76}$ Still, wind power has developed as a conservative invention, rather than the basis for radical change in the existing system.

Meanwhile, how do we interpret the apparently radical change in some managers' attitudes, as expressed by their adoption of DSM? Why are they so eager to cede some control to outsiders-especially outsiders who had, until recently, been their staunch opponents? The simplest, most straightforward reason is that utilities need to remain in the good graces of regulatory commissions. Trying to mitigate the price hikes of the 1980s, regulators looked to DSM as a way to reduce pressure to build expensive new power plants. Though resisting, utilities went along with regulators to obtain different benefits (such as a financially satisfying rate of return on other investments).

The case of Central Maine Power in the 1980s provides a dramatic example of this behavior. Seeking rate increases to pay for its share of the long-delayed Seabrook nuclear power plant in New Hampshire, and hoping for approval of plans to establish unregulated subsidiaries, the company lost credibility with Maine commissioners when a vice president admitted to perjury in a hearing. The event caused a corporate shakeout and, in 1984, John Rowe, a Wisconsin lawyer with no utility experience, took control of the firm. Seeking to placate regulators, he embraced DSM and cogeneration technologies-favored by the commissioners but dismissed by previous company executives. While Rowe appreciated how DSM could fit into

\footnotetext{
${ }^{76}$ Early champions of wind power presented it as an electric supply option with zero environmental cost. Neighbors of early turbines hotly disputed that assessment, pointing to noise and television interference. These problems have been reduced, but protests on the basis of the turbines' visual impact continue. More recently, influential environmentalists, such as the chief scientist of the National Audubon Society, have called for a moratorium on turbine construction because of the birds of prey killed by flying into the rotor blades. See Ellen Paris, "Palm Springs and the Wind People," Forbes 135 (June 3, 1985): 170-71; P. B. Bosley and K. W. Bosley, "Risks and Benefits of Wind Generated Electricity: Facts and Perceptions," Energy Sources 14 (January-March 1992): 1-9; and Teresa Tamkins, "Tilting at Wind Power," Audubon 95 (September-October 1993): 24, 26, 28.
} 
his company's strategy for avoiding participation in new power-plant construction programs, he nevertheless expected to score valuable points by complying with the commissioners' desires. As a result, he rebuilt the trust and cooperation between the company and the regulatory body, which proved vital for the utility's financial turnaround.$^{77}$ While unique, this story illustrates the role DSM can play in reestablishing good will between antagonistic power executives and regulators.

Utility managers may have accepted DSM for other reasons too. Some critics of utility DSM programs charge that managers are abdicating control over some parts of their business in order to retain control over others. In particular, managers may be embracing conservation on the demand side of their business to limit competition with other power generators on the supply side. They accomplished this goal, the argument goes, by urging the states' regulatory commissions to make DSM part of their forward-looking energy resource plans. In California, for example, the Public Utilities Commission (with the approval of the California Energy Commission) approved plans for the state's utilities to meet a large fraction of the anticipated demand for power during the 1990s with DSM programs. While some of the programs would be pursued by independent energy service companies, most would be undertaken by the utilities themselves. Regardless of who performs the DSM work, however, the net effect is to reduce the need for supply-side resources. Hence, the state regulatory agencies, by approving DSM plans, have restricted the amount of business that independent power producers can gain. This outcome suits utility managers, as it allows them to retain technological and financial control over "their" system. ${ }^{78}$

Critics maintain that DSM inhibits independent power producers in another way. It may happen that, later in the 1990s, utilities will find that their projections for replacing generation supply with DSM have fallen short. At that time, the companies will argue that they can refurbish old, utility-owned plants and provide power at a lower cost than could competitors. As noted by Jan Smutney-Jones, executive director of the state's Independent Energy Producers Association, "there's a high degree of suspicion from the independent suppliers of electricity that DSM is actually being used as sort of a marketing tool, at least in the short run to suppress the [indepen-

${ }^{77}$ Julie Lanza, “John W. Rowe: Creative Energy,” Boston Business Jourmal 12 (February 12, 1993), sec. 1, p. 19.

${ }^{78}$ Karen Morris, "California DSM Programs Anticompetitive," DSM Quarterly (Summer 1992): 6-9. 
dent power] market. My suspicion is that [the utilities] are using DSM in the front part of the 90s to suppress the need for adding new independents, and then later in the decade will be in the mode of repowering their own plants." In sum, Smutney-Jones argues, "the utilities' strategy is to use the regulatory system to maintain market control.",79

As historians, we find such an interpretation based on self-interest plausible, insofar as it outlines possible scenarios of the effects of DSM programs. If DSM makes new generating capacity unnecessary in the immediate future, independent producers, rather than utilities, will indeed be inhibited. Utility managers, then, will have found another way to retain control over the system. Nevertheless, we are cautious about imputing conscious political motives to utility managers who support DSM. Certainly, no executives have ever admitted to us that their companies pursue DSM merely to prevent independents from gaining market power. Nor are we sure what such an admission would mean. ${ }^{80}$

More important, historians must be careful not to view utilities as

${ }^{79}$ Ibid., p. 8. Utility managers are not the only actors who have the opportunity to retain control of the existing utility system in this DSM scenario. Some critics of utility DSM programs argue that environmental advocates and regulators also benefit. Environmentalists profit by having their goals endorsed by regulatory commissions, which gives them public credibility and wins them entree into the boardrooms of utility companies. No longer dismissed as extremists, environmentalists now appear as insiders, part of the establishment, thus strengthening their positions in future policy debates. Meanwhile, regulators may see DSM as a way to retain their own power. As the industry becomes more competitive, the role of regulators as overseers of utility capital projects and ensurers of "fair" rates for customers diminishes. Because environmental activities such as conservation have widespread public support, DSM offers regulators a way to legitimize a new set of activities while they lose control over traditional utility actions. At the same time, some managers argue that customers will benefit through conservative change: not only is conventional utility management safer and more reliable than entrepreneurial activity, they suggest it is cheaper too, because utilities enjoy access to cheaper sources of long-term capital than do entrepreneurs. In short, adoption of radical-looking DSM programs offers a chance for many of today's participants in the utility community to maintain the system in a way that allows them to retain some elements of control. This selfinterest interpretation is also known as a "rent-seeking" model of political economy. See James M. Buchanan, Robert D. Tollison, and Gordon Tullock, eds., Toward a Theory of the Rent-Seeking Society (College Station, Tex., 1980). For a critical view of the role of participants in the political economy of the utility industry, see Douglas A. Houston, Demand-Side Management: Ratepayers Beware! 2d ed. (Houston, 1993), pp. $36-41$.

${ }^{80}$ The intentions of historical actors, or rather their first-person accounts of their intentions, offer problematic historical evidence at best. We doubt, in any case, that history should take as its primary goal the explication of individuals' intentions. 
single historical actors with a single motive. At a finer grain of internal detail, utilities show a variety of tendencies, some of which conflict. For example, in 1984 Southern California Edison hired John Bryson, cofounder of the National Resources Defense Council, as executive vice president. ${ }^{81}$ While Bryson may consider himself a business pragmatist, he also provides a strong voice for environmental values within the company, especially since becoming the company's chairman and CEO in $1991 .^{82}$ With regard to DSM, then, we doubt that utility managers speak with one voice, or that they act for a single reason, or even that they are aware of all the consequences of their actions.

Despite these reservations about the single-mindedness of historical actors, we argue that employment of wind turbines and DSM techniques constituted responses to conserve the utility system with as little change as possible. But beyond this conclusion, our study offers some useful methodological insights into the role played by technology (and its creators) for altering the momentum of systems. In particular, the examination of the threats posed by wind power and DSM to the utility system gives us a way to sharpen the methodological value of Hughes's notion of radical and conservative technologies. Hughes implies that negotiations concerning acceptance of a new technology hang on whether the invention is essentially radical or conservative. Yet, in the story of wind power and DSM, those attributes resulted from negotiations. Nothing inherent in the technologies determined that they would be used either to destroy the existing system nor enhance its stability.

In the terminology we have been using, the technologies could have been considered either conservative or radical. Some actors lobbied for utilities to adopt wind power, for example, as simply another supply option in the grid they owned and managed. Others pushed for privately owned windfarms, mostly outside the utilities' control. Still other actors envisioned wind power as a household or community-based energy option able to provide a radical alternative to the established electric system. Likewise, some advocates of energy efficiency expected that utilities would shy away from a business that appeared to have little to do with their core competency of generating and distributing an electrical commodity. But environmental activists, regulatory commissioners, and utility managers turned DSM

\footnotetext{
${ }^{81}$ Marc Reisner, "The Most Imaginative Power Company in the US," Science Digest (August 1986): 63-87.

${ }^{82}$ Peter Nulty, "Finding a Payoff in Environmentalism," Fortune, October 21, 1991, p. 79 .
} 
into a lucrative business that enhanced the political and institutional power utilities could wield. In other words, the technologies did not exert a one-way influence on their environment, as if a radical or conservative character was embedded in their design. Those qualities had to be determined as a result of negotiations between actors in the system.

This modification of Hughes's notion of conservative and radical inventions should prove useful to those who employ the systems approach. It will also benefit us as we continue to explore the possibility that the American utility system has been radically transformed. Though we have described here how power company managers have successfully digested the threats of wind power and DSM to the utility system, we realize that other events have occurred recently that continue to challenge the system's integrity. In particular, new smallscale technologies have been evolving that allow individual homes and businesses to produce power for themselves and sell excess capacity to other users, thus reducing the need for customers to be hooked up to the grid at all. At the same time, political pressure has intensified to eliminate the regulatory framework altogether and to allow greater competition among vendors of electricity-all enabled through the use of new technologies for generating power and for coordinating its movement through the grid or small, localized networks. Clearly, these events may constitute perils that eclipse the destabilizing effects of wind power and DSM. To determine whether the traditional stakeholders in the American electric power matrix have permanently succeeded in conserving their system, we will therefore need to focus on the ongoing negotiations among participants about the potentially radical nature of new technologies. ${ }^{83}$

\footnotetext{
${ }^{83}$ Richard Hirsh is currently completing a book manuscript that plans to offer a more definitive characterization of the contemporary electric utility system.
} 